\title{
Xanthone biosynthesis in Hypericum perforatum cells provides antioxidant and antimicrobial protection upon biotic stress
}

\author{
Gregory Franklin ${ }^{a}$, Luis F.R. Conceição ${ }^{a}$, Erich Kombrink ${ }^{b}$, Alberto C.P. Dias ${ }^{\mathrm{a}, *}$ \\ a Departamento de Biologia, Universidade do Minho, Campus de Gualtar, 4710-057 Braga, Portugal \\ ${ }^{\mathrm{b}}$ Department of Plant-Microbe Interactions, Max Planck Institute for Plant Breeding Research, Carl-von-Linné-Weg 10, 50829 Köln, Germany
}

\section{A R T I C L E I N F O}

\section{Article history:}

Received 13 May 2008

Received in revised form 18 October 2008

Available online 4 December 2008

\section{Keywords:}

Agrobacterium

Hypericum perforatum

Biotic stress

Xanthones

Antioxidant defense response

Elicitation

Phytoalexins

\begin{abstract}
A B S T R A C T
Xanthone production in Hypericum perforatum (HP) suspension cultures in response to elicitation by Agrobacterium tumefaciens co-cultivation has been studied. RNA blot analyses of HP cells co-cultivated with $A$. tumefaciens have shown a rapid up-regulation of genes encoding important enzymes of the general phenylpropanoid pathway (PAL, phenylalanine ammonia lyase and 4CL, 4-coumarate:CoA ligase) and xanthone biosynthesis (BPS, benzophenone synthase). Analyses of HPLC chromatograms of methanolic extracts of control and elicited cells (HP cells that were co-cultivated for $24 \mathrm{~h}$ with A. tumefaciens) have revealed a 12-fold increase in total xanthone concentration and also the emergence of many xanthones after elicitation. Methanolic extract of elicited cells exhibited significantly higher antioxidant and antimicrobial competence than the equivalent extract of control HP cells indicating that these properties have been significantly increased in HP cells after elicitation. Four major de novo synthesized xanthones have been identified as 1,3,6,7-tetrahydroxy-8-prenyl xanthone, 1,3,6,7-tetrahydroxy-2-prenyl xanthone, 1,3,7-trihydroxy-6-methoxy-8-prenyl xanthone and paxanthone. Antioxidant and antimicrobial characterization of these de novo xanthones have revealed that xanthones play dual function in plant cells during biotic stress: (1) as antioxidants to protect the cells from oxidative damage and (2) as phytoalexins to impair the pathogen growth.
\end{abstract}

() 2008 Elsevier Ltd. All rights reserved.

\section{Introduction}

Hypericum, a genus of the family Clusiaceae, is widely used in traditional medicine throughout the world since ancient times. The genus is known to produce several xanthones (Dias et al., 2000, 2001; Dias, 2003; Ferrari et al., 2005; Tanaka and Takaishi, 2006).

Xanthones are a class of polyphenolics that exhibit well-documented pharmacological properties, mainly due to their oxygenated heterocyclic nature and diversity of functional groups. They have been described as strong scavengers of free radicals (Jiang et al., 2004). In addition, many of the xanthones have been reported to be active against bacteria including methicillin/multidrug resistant Staphylococcus aureus (Rukachaisirikul et al., 2003, 2005; Sukpondma et al., 2005; Xiao et al., 2008), vancomycin resistant Enterococci (Sakagami et al., 2005), Mycobacterium tuberculosis (Suksamrarn et al., 2003), etc. Some xanthones even surpass the antimicrobial activity of traditional antibiotics (Iinuma et al., 1996; Xiao et al., 2008). Other pharmacological properties of xanthones include anti-inflammatory (Banerjee et al., 2000), cancerchemopreventive (Ito et al., 2003), hepatoprotective (Tian et al.,

\footnotetext{
* Corresponding author. Tel.: +351 253604317/18; fax: +35153678980.

E-mail address: acpdias@bio.uminho.pt (A.C.P. Dias).
}

2005), cardiovascular protective (Jiang et al., 2004), selective inhibition of cyclooxygenase-2 (Zou et al., 2005), inhibition of plateletactivating factor (PAF)-induced hypotension (Ishiguro et al., 2002; Oku et al., 2005) and cytotoxic activities (Yimdjo et al., 2004; Boonsri et al., 2006; Suksamrarn et al., 2006).

Plant cells respond to pathogens predominantly by mobilizing their secondary metabolites, which tend to protect the plant cells from pathogen attack. In this context, Beerhues and Berger (1995) observed an increase in xanthone accumulation in suspended cells of Centaurium species upon elicitation with yeast extract and methyl jasmonate (MeJ). Conceição et al. (2006) observed a similar response (xanthone accumulation) in Hypericum perforatum suspended cells elicited with Colletotrichum gloeosporioides cell wall extracts. The induced xanthone accumulation was further increased (by at least 12-fold) when the HP cells were primed with either MeJ or salicylic acid (well known defense signaling compounds in plants), an important observation, which explains possible role of xanthones in plant cells under biotic stress.

Here, we show that the antioxidant and antimicrobial potentials have been significantly increased in HP cells after elicitation with Agrobacterium tumefaciens due to the rapid up-regulation of xanthone metabolism. Putative roles of xanthone metabolism in HP cells under conditions of biotic stress are discussed. 


\section{Results and discussion}

\subsection{Induction of xanthone biosynthesis is a defense response}

2.1.1. Xanthone profile of HP cells was altered after co-cultivation with A. tumefaciens

Major classes of phenolic compounds produced by cultured HP cells under normal conditions are flavonoids and xanthones (Fig. 1a, F, flavonoid and X, xanthone). Though the flavonoid profile remained unaltered after elicitation, xanthone profile has significantly changed within $24 \mathrm{~h}$ (Fig. 1b). With new xanthones, the total xanthone content increased 12-fold (Fig. 2) indicating that xanthone biosynthesis has potential role in the biotic interaction. Similar patterns of xanthone accumulation has also been observed in
HP cells that were elicited with fungal extracts or primed with plant defense signaling compounds such as MeJ and salicylic acid (Conceição et al., 2006). Likewise, xanthones were seen accumulated when cell cultures were treated with MeJ and yeast-extract in Centaurium species (Beerhues and Berger, 1995), $H$. androsaemum and Centaurium erythraea (Abd El-Mawla et al., 2001); the latter cell cultures exhibited new xanthones after MeJ treatment. All these observations support the participation of xanthones in plant defense response.

Although mangiferin (peak denoted as ' $M$ ') found along with few other unidentified xanthones in both control and treated cells, new xanthones appeared in the HP cells treated with $A$. tumefaciens (Figs. 1a and b). Amongst the up-regulated xanthones, four were identified (Fig. 1b, peaks 1-4, see Fig. 1c for structural formulae)
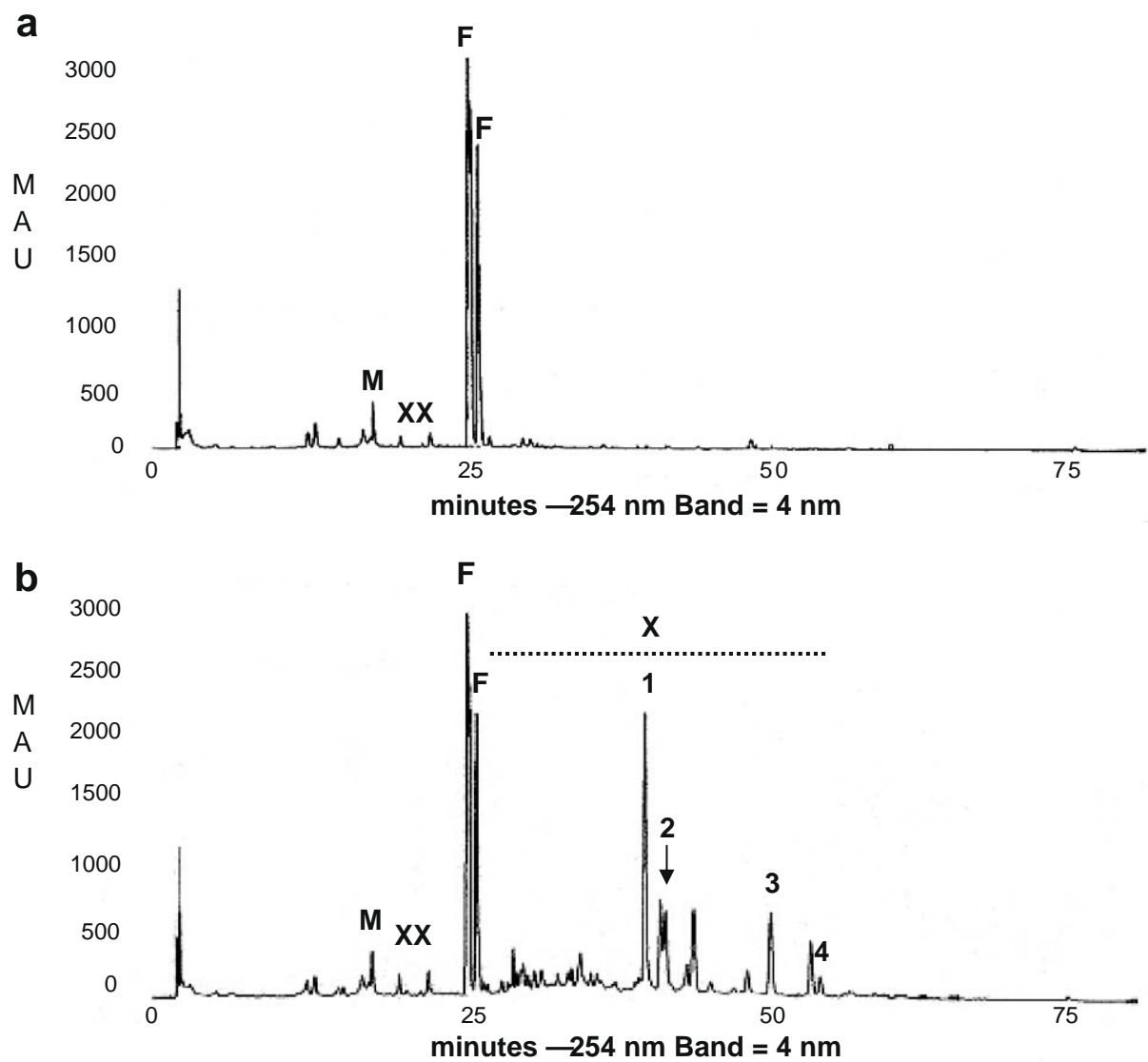

C

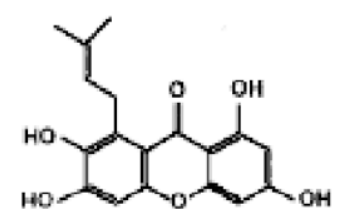

1,3,6,7-tetrahydroxy-8-prenyl xanthone

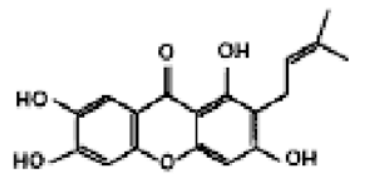

1,3,6,7-tetrahydroxy-2-prenyl xanthone<smiles>CC(C)=CCc1c(O)c(O[Na])cc2c1C(O)c1c(O)cc(O)cc1O2</smiles>

1,3,7-trihydroxy-6-methoxy-8-prenyl xanthone paxanthone

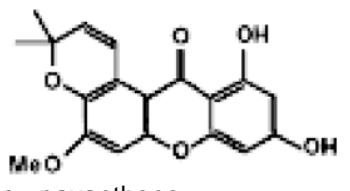

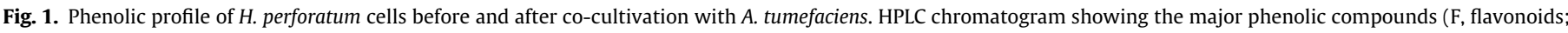

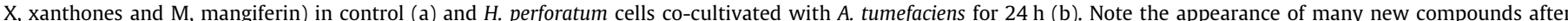

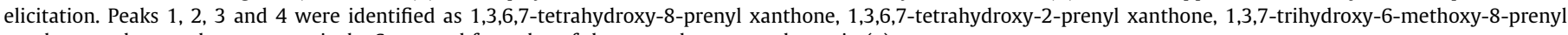
xanthone and paxanthone, respectively. Structural formulae of these xanthones are shown in (c). 


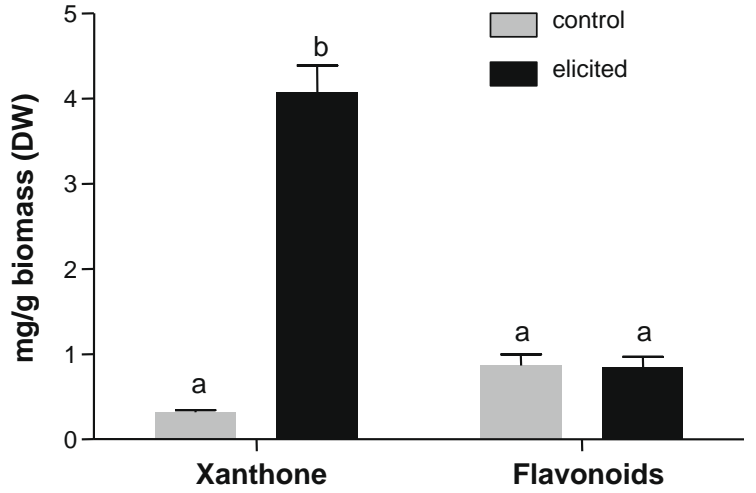

Fig. 2. Graph representing total xanthones and flavonoids content of the control and treated $H$. perforatum cells showing a dramatic increase of xanthones in HP cells co-cultivated for $24 \mathrm{~h}$ with $A$. tumefaciens. Values are represented in mean $\pm \mathrm{SE}$; bars indicated with different letters in a pair are significantly different $(p<0.001)$, note: between control and elicited cells, flavonoid concentration is not significantly different $(p>0.05)$, whereas xanthone concentration is significantly different $(p<0.001)$ Bonferroni test.

as 1,3,6,7-tetrahydroxy-8-prenyl xanthone (peak 1), 1,3,6,7-tetrahydroxy-2-prenyl xanthone (peak 2), 1,3,7-trihydroxy-6-methoxy-8-prenyl xanthone (peak 3) and paxanthone (peak 4). Concentrations of those xanthones before and after elicitation are shown in Table 1 . The major xanthone in the treated HP cells was 1,3,6,7-tetrahydroxy-8-prenylxanthone, which accounted for $23 \%$ of the total xanthones (Table 1 ). This was found to be the same compound that was elicited by MeJ in $\mathrm{H}$. androsaemum cell cultures (Abd El-Mawla et al., 2001), and, might be a common compound induced in both $H$. perforatum and $H$. androsaemum in response to the biotic stress.

\subsubsection{Xanthone production in response to elicitation by A. tumefaciens} is regulated by transcriptional control of enzymes participating in the xanthone biosynthesis pathway

BPS gene expression was found to be strongly up-regulated in HP cells upon treatment with $A$. tumefaciens as revealed by northern blot analysis (Fig. 3d). While BPS transcripts were undetectable in control HP cells, they accumulated within $4 \mathrm{~h}$ of $A$. tumefaciens challenge, and reached the maximum in $12 \mathrm{~h}$ and declined then on. A more or less similar pattern of expression was observed for PAL gene (Fig. 3b), which is participating in the biosynthesis of xanthone precursor and $4 \mathrm{CL}$ gene (Fig. $3 \mathrm{c}$ ) that is related to the ubiquitous activation of general phenylpropanoid pathway following elicitation. The changes in the PAL MRNA levels agree quite well with the changes in the PAL activity level in elicited $H$. androsaemum cell cultures (Abd El-Mawla and Beerhues, 2002).

The rapidly induced expression of PAL, 4CL and BPS genes in HP cells co-cultivated with $A$. tumefaciens indicates that the xanthone biosynthetic pathway is activated immediately after sensing the pathogen. PAL, the first enzyme of the general phenylpropanoid pathway, catalyses the deamination of phe to cinnamic acid. Cin-

Table 1

Xanthone content ( $\mu \mathrm{g} / \mathrm{g}$ dry wt) of HP cells before and after elicitation.

\begin{tabular}{lll}
\hline & $\begin{array}{l}\text { Control HP } \\
\text { cells }\end{array}$ & $\begin{array}{l}\text { Elicited HP } \\
\text { cells }\end{array}$ \\
\hline $\begin{array}{l}\text { 1,3,6,7-Tetrahydroxy-8-prenyl xanthone } \\
\text { 1,3,6,7-Etrahydroxy-2-prenyl xanthone }\end{array}$ & 0 & 950 \\
$\begin{array}{l}\text { 1,3,7-Trihydroxy-6-methoxy-8-prenyl } \\
\quad \text { xanthone }\end{array}$ & 0 & 270 \\
$\begin{array}{l}\text { Paxanthone } \\
\text { Total xanthones }\end{array}$ & 0 & 270 \\
\hline
\end{tabular}

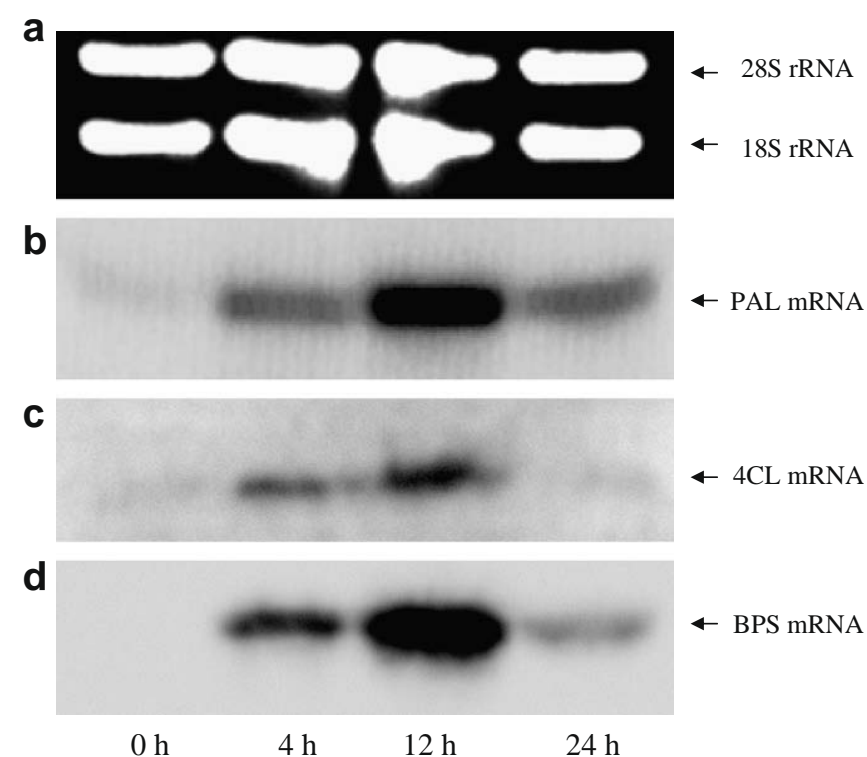

Fig. 3. Northern blot analysis of total RNA isolated from $H$. perforatum cells after cocultivation with A. tumefaciens. Ethidium bromide stained rRNA on the Northern blot to show loading (a); blots showing the up-regulation of phenylalanine ammonia lyase (b); 4-coumarate:CoA ligase (c) and benzophenone synthase and (d) genes expression within $4 \mathrm{~h}$ reaching the maximum in $12 \mathrm{~h}$ and declining thereafter. Control $H$. perforatum cells $(0 \mathrm{~h})$ does not have any hybridization signal for BPS indicating that the xanthone metabolism is activated only after $A$. tumefaciens co-cultivation.

namic acid, which is used in the synthesis of benzoic acids, the precursors of xanthone biosynthesis (Abd El-Mawla et al., 2001) thus, plays a key role in diverting photosynthate from primary metabolism to phenylpropanoid metabolism. BPS is an important enzyme, which catalyses the stepwise condensation of activated benzoic acids with three molecules of malonyl-CoA (Beerhues, 1996; Schmidt and Beerhues, 1997) and the resulting benzophenones undergo intra-molecular cyclization to give xanthones (Peters et al., 1998). The enzyme 4CL plays a key role in channelling carbon flow into diverse branch pathways of phenylpropanoid metabolism, which serves important functions in plant growth and adaptation to environmental perturbations (Ehlting et al., 1999).

Activation of phenylpropanoid metabolism has been described as an almost ubiquitous feature of plant response to stress conditions (Dixon and Paiva, 1995). Marked increase in PAL synthesis and corresponding mRNA accumulation occur in response to microbial or endogenous elicitors has been reported in many plant-pathogen systems (Sharan et al., 1998). Thus, xanthone biosynthesis in response to $A$. tumefaciens treatment is believed to be regulated by transcriptional control of enzymes participating in the pathway.

\subsection{Xanthones protect HP cells from oxidative stress}

\subsubsection{ROS scavenging potential of HP cells increases after elicitation with A. tumefaciens}

HP cells taken at different time intervals $(0,15,30,60,120,180$ and $240 \mathrm{~min}$ ) following $A$. tumefaciens challenge were incubated with $\mathrm{H}_{2}$ DCFDA, a probe that measures the cellular ROS levels internally. HP cells produced a biphasic oxidative burst after the challenge (Fig. 4a) an observation already reported (Franklin et al., 2008). Because of the highly cytotoxic and reactive nature of ROS, their accumulation must be under tight control (Shao et al., 2008). If not scavenged, the ROS would eventually lead to critical levels of $\mathrm{H}_{2} \mathrm{O}_{2}$ (Scandalios, 1993). Such levels are detrimental to 

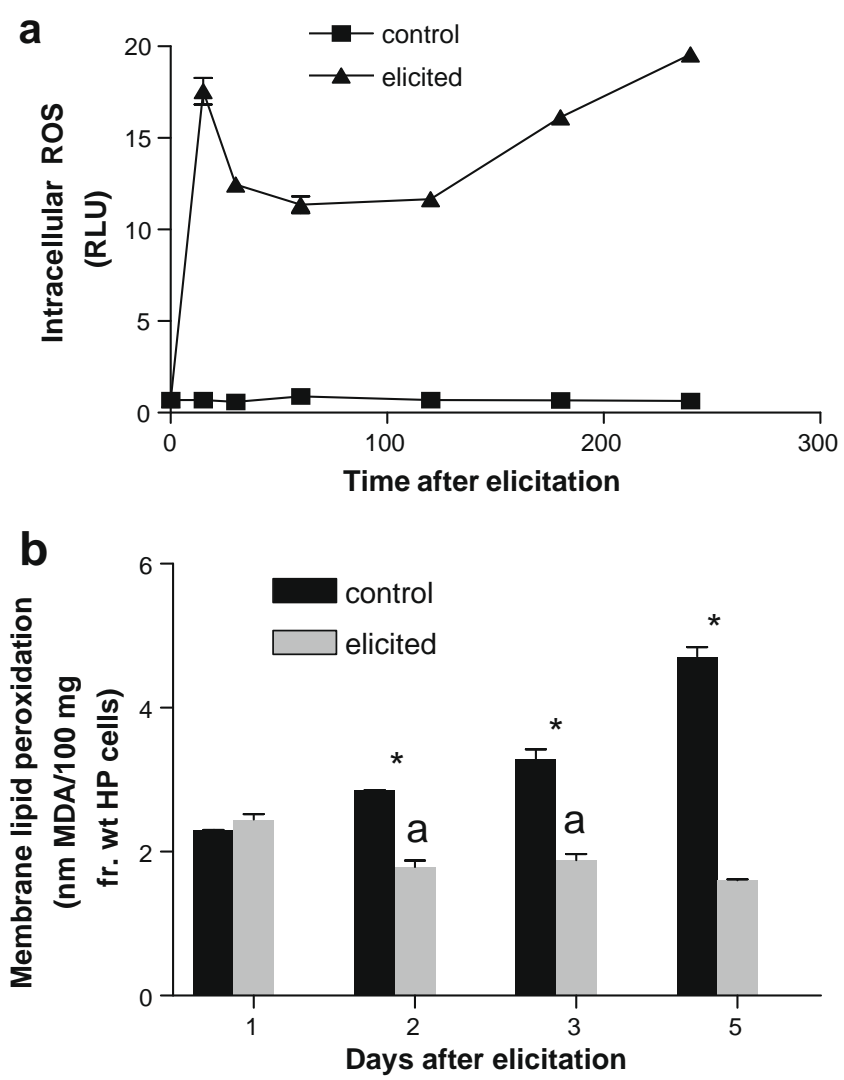

Fig. 4. Physiological status of $H$. perforatum cells during A. tumefaciens cocultivation. Intracellular reactive oxygen species (ROS) production in $H$. perforatum cells showing biphasic oxidative burst, characteristic of an incompatible plantpathogen interaction (a) and ROS production at different time points are indicated in mean \pm SE. ROS production is significantly different between control and treatment $(p<0.001$, Bonferroni test). Membrane lipid peroxidation in $H$. perforatum cells during co-cultivation with $A$. tumefaciens (b). Values represented in mean \pm SE; pairs indicated with an asterisk ( $\left.{ }^{*}\right)$ are significantly different $(p<0.001$, Bonferroni test); all the values are different except those indicated with the same letter.

the cellular macromolecules of both the pathogen and the host and thus might lead to cell death in both organisms.

The rate of membrane lipid peroxidation in untreated (control) HP cells doubled (from approximately 23 to $47 \mathrm{nmol} \mathrm{MDA} / \mathrm{g}$ fr. wt) as the cultures aged (during the experimental period of 5 days, Fig. 4b); whereas in the HP cells that have been co-cultivated with A. tumefaciens, the level of membrane lipid peroxidation remained similar to the control on day one and thereafter significantly declined to about $70 \%$ of its initial value (16 vs. $23 \mathrm{nmol} \mathrm{MDA} / \mathrm{g}$ fr. wt) over the period of 5 days, in spite of the intense oxidative burst observed. Moreover, HP cells retained $100 \%$ viability throughout the experimental with and without the pathogen. This observation has been reported before (Franklin et al., 2008).

Analysis of the culture medium of the elicited HP cultures (by xylenol orange method) did not show the presence of $\mathrm{H}_{2} \mathrm{O}_{2}$. This indicated that the intense oxidative burst produced internally in the HP cells was not transported outside of the cells. Absence of $\mathrm{H}_{2} \mathrm{O}_{2}$ in the extracellular medium further suggests that the ROS produced by HP cells might have been readily scavenged either before or immediately after their conversion into $\mathrm{H}_{2} \mathrm{O}_{2}$.

\subsubsection{Increased ROS scavenging potential of elicited HP cells is due to induced xanthone biosynthesis}

In order to determine whether the xanthones synthesized anew by the cells after elicitation (Fig. 1b) have ROS scavenging activity, we compared the antioxidant potential of the total phenolics of both the control and elicited HP cells that was extracted with $\mathrm{MeOH}$ from (co-cultivated with A. tumefaciens for $24 \mathrm{~h}$ ) in two different antioxidant model assays (DPPH reduction and TBARS). Methanolic extracts of elicited cells showed a higher degree of radical scavenging activity (DPPH reduction) with a greater capacity for preventing synaptosomal lipid peroxidation, than equivalent extracts obtained from non-elicited (control) cells (Figs. 5a and b).

In DPPH reduction assay, the $\mathrm{EC}_{50}$ values were $0.7 \mathrm{mg}$ dry $\mathrm{wt} / \mathrm{ml}$ and $0.44 \mathrm{mg}$ dry $\mathrm{wt} / \mathrm{ml}$ respectively for the control and elicited cells (Fig. 5a). Similarly in synaptosomal lipid peroxidation inhibition assay, the $\mathrm{EC}_{50}$ values were $0.17 \mathrm{mg}$ dry $\mathrm{wt} / \mathrm{ml}$ and $0.04 \mathrm{mg}$ dry $\mathrm{wt} / \mathrm{ml}$ respectively for the control and elicited cells (Fig. 5b). Altogether, the free radical scavenging capacity was increased 0.6 -fold and the protection against membrane lipid peroxidtion was increased about 3.25-folds in HP cells after elicitation. The increased antioxidant activity can possibly be attributed to the large amounts of xanthones produced in HP cells after elicitation.

In the present study, the first ROS burst (Fig. 4a) occurred relatively earlier (in $15 \mathrm{~min}$ ) than the up-regulation of xanthone biosynthesis (BPS mRNA starts to accumulate at $4 \mathrm{~h}$ and attain maximum at $12 \mathrm{~h}$ ) after treating with the bacterium. In fact, this burst was seen to be short-lived and might have been buffered by the existing phenolics (xanthones plus flavonoids). Our hypoth-
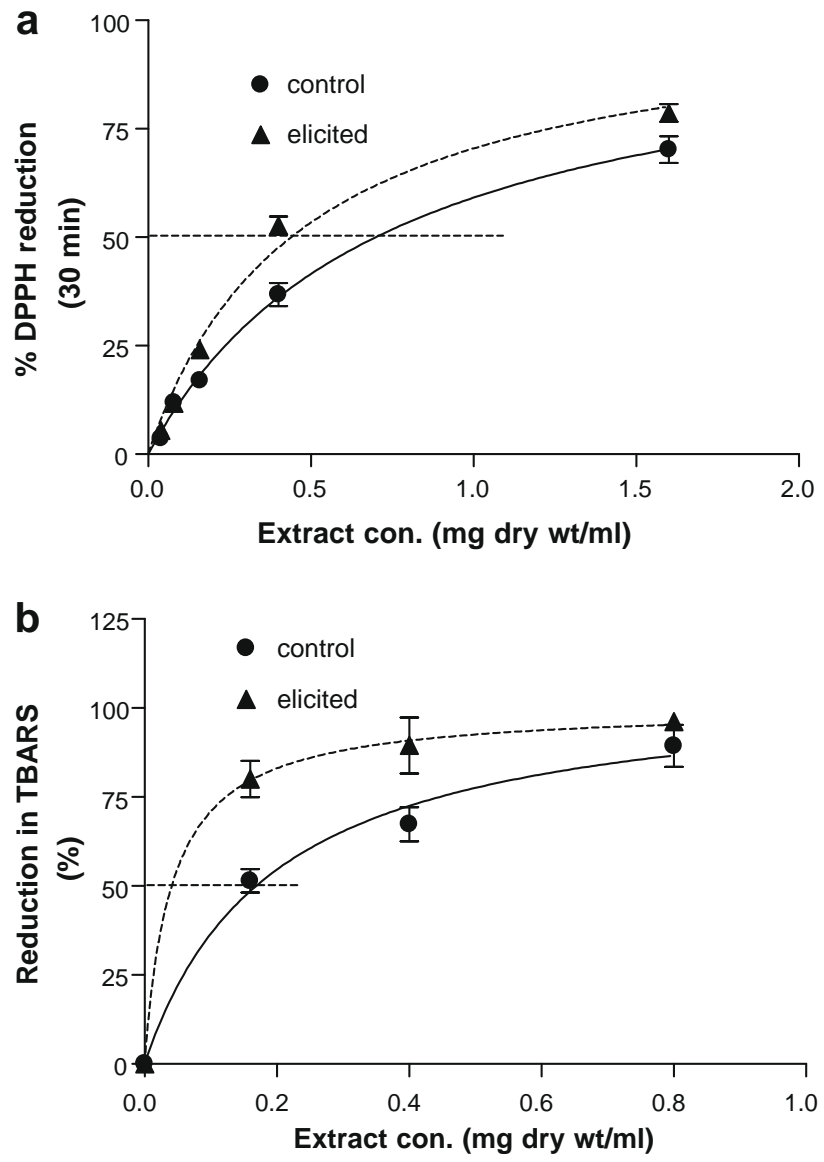

Fig. 5. Antioxidant potential of $H$. perforatum cells after $24 \mathrm{~h}$ co-cultivation with $A$. tumefaciens. Methanolic extract of elicited $H$. perforatum cells showing more efficient DPPH reduction than the methanolic extract of control cells (a) and values are the mean $\pm \mathrm{SE}$ of three independent experiments. DPPH reduction is significantly higher in methanolic extract of elicited cell than the control at $0.16 \mathrm{mg} / \mathrm{ml}$ ( $p<0.01$, Bonferroni test) and higher concentrations tested $(p<0.001$, Bonferroni test). Likewise, inhibition of synaptosomal lipid peroxidation is higher in the methanolic extract of elicited cells than control cells (b). 
esis that the oxidative burst that occurred in the initial phase of the incompatible plant-pathogen interactions is responsible for the induction of defense reactions agrees with that of Arias et al. (2005). Moreover, ROS has complex downstream effects on secondary metabolism as signalling molecules (Chen et al., 1993; Vanderauwera et al., 2005; Foyer and Noctor, 2005). Hence, the first ROS burst could have acted as signal to prime the xanthone biosynthesis, and the massive xanthone production could be related to the second phase of ROS production, which is more intense and long-lasting, as we observed. During such state and thereafter, the cells would need additional antioxidant support conferred by xanthones produced anew, to achieve cellular ROS homeostasis.

\subsubsection{De novo synthesized xanthones have antioxidant properties}

In order to check the contributions of the de novo xanthones in the hiked antioxidant potential of elicited cells, we studied the antioxidant efficacies of the four xanthones identified in elicited HP cells methanolic extract (Fig. 1c). These xanthones showed antiradical activity (DPPH reduction) to varying degrees (Fig. 6a) and were very effective in protecting against synaptosomal lipid peroxidation (Fig. 6b). The synaptosomal lipid peroxidation inhibitory activity of 1,3,6,7-tetrahydroxy-8-prenyl xanthone $\left(\mathrm{EC}_{50}=\right.$ $0.08 \mu \mathrm{g} / \mathrm{ml}$, Fig. 6b) was the highest among tested xanthones. Complete inhibition of induced synaptosome lipid peroxidation by this xanthone even at considerably low concentration $(1.0 \mu \mathrm{g} / \mathrm{ml})$ indicates that even a small increase could have significant antioxidant protection for the host cells.

Previous studies (Pinto et al., 2005; Foti et al., 2005) have shown that xanthones could effectively suppress ROS production and pre-
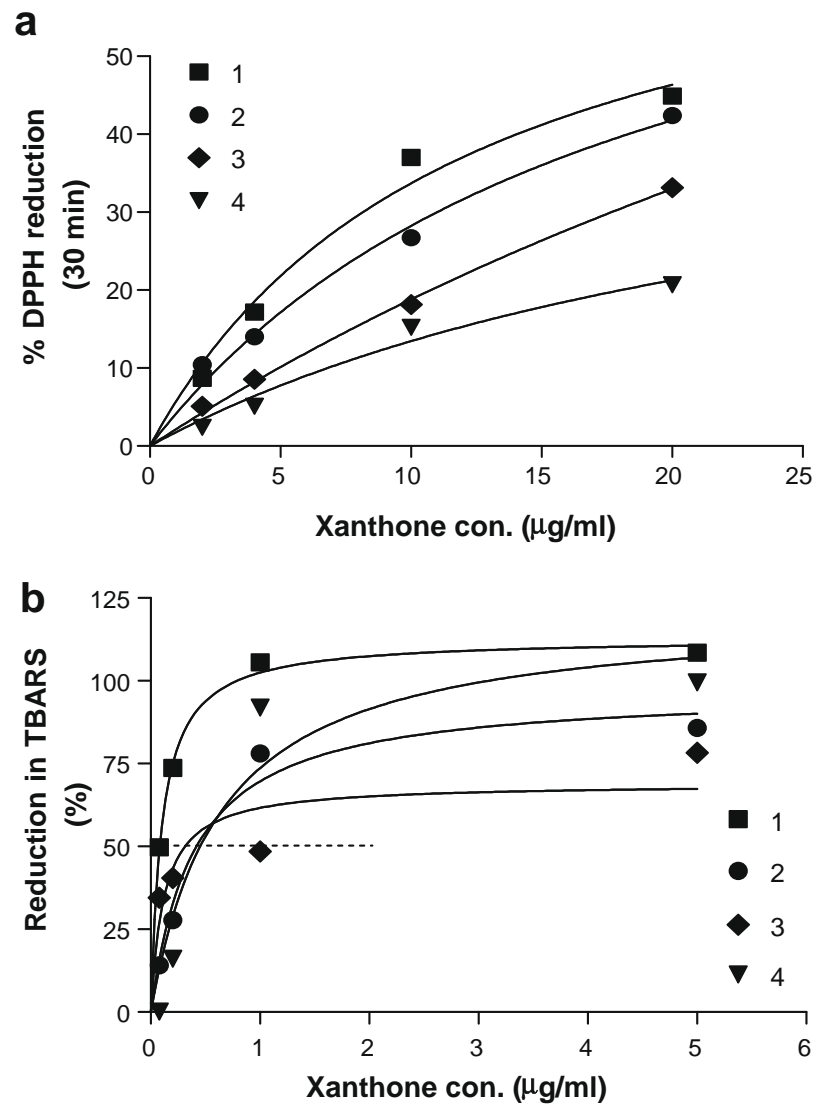

Fig. 6. DPPH reduction (a) and synaptosomal lipid peroxidation inhibition (b) potentials of four identified xanthones; 1,3,6,7-tetrahydroxy-8-prenyl xanthone (1), 1,3,6,7-etrahydroxy-2-prenyl xanthone (2), 1,3,7-trihydroxy-6-methoxy-8-prenyl xanthone (3) and paxanthone (4) vent lipid peroxidation. Hence, we conclude that the up-regulation of xanthone biosynthesis aids HP cells to defend against biotic stress produced during the pathogenic challenge. This hypothesis could also explain the long-term viability/survival of HP cells during extended periods of pathogenic interactions (Franklin et al., 2007, 2008).

\subsection{Xanthones provide antimicrobial protection to HP cells}

\subsubsection{Antimicrobial potential of HP cells increased after elicitation}

It was remarkable to find the viability of $A$. tumefaciens gradually declining reaching $(<1 \%)$ after $12 \mathrm{~h}$ of co-cultivation (Franklin et al., 2008) and the decline was about $50 \%$ at 5-6 h, at a time when xanthones start accumulating (Abd El-Mawla and Beerhues, 2002). To check whether the induced xanthone biosynthesis of HP cells is responsible for the reduced bacterial viability, we compared the antimicrobial potentials of methanolic extracts of control and cells co-cultivated with A. tumefaciens for $24 \mathrm{~h}$ period. Concentrations of methanolic extracts equivalent to $20 \mathrm{mg}$ dry wt elicited HP cells/ml and $200 \mathrm{mg}$ dry wt control HP cells $/ \mathrm{ml}$ could kill $250 \times 10^{7}$ A. tumefaciens cells within 24 h of incubation
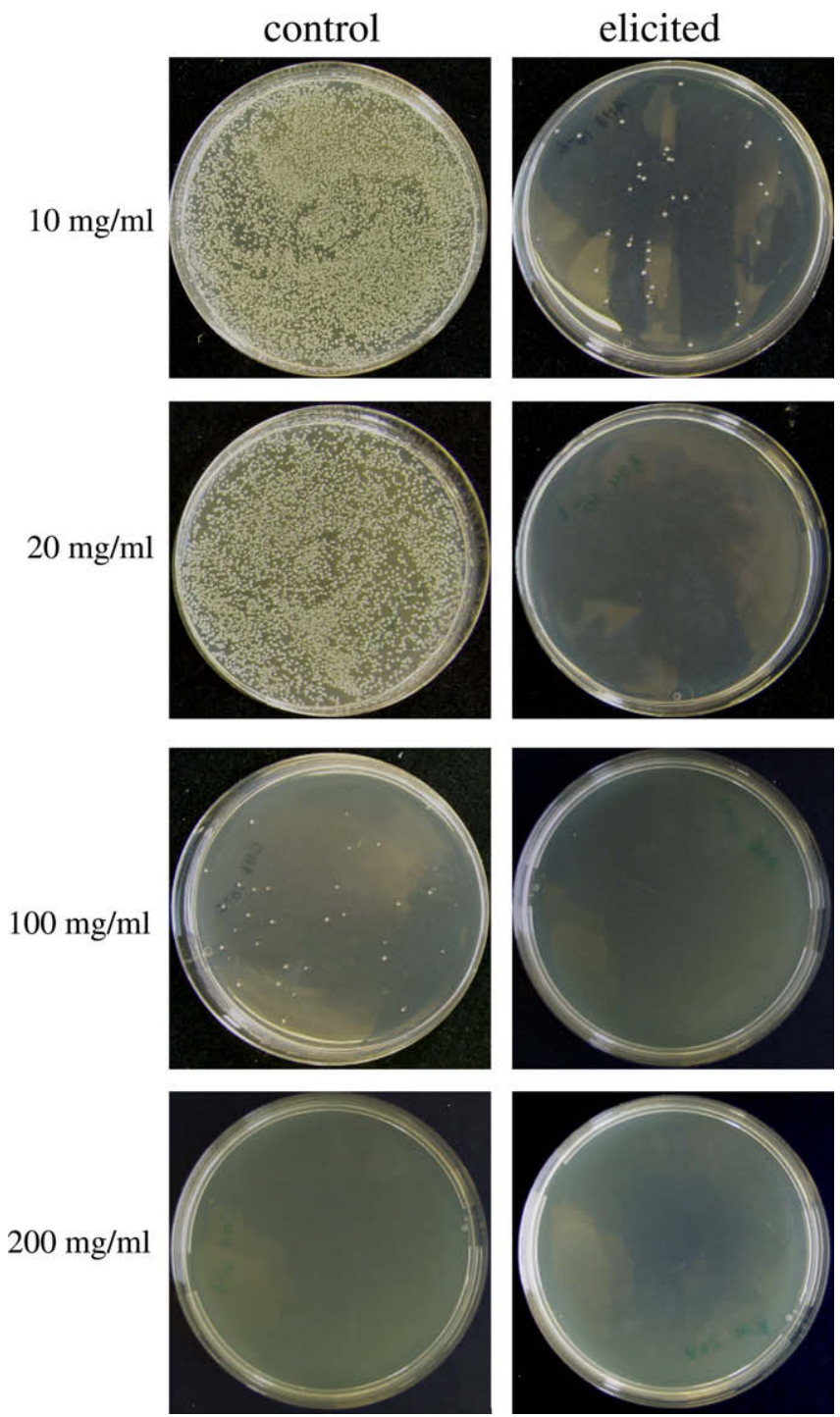

Fig. 7. Antimicrobial potential of $H$. perforatum cells after $24 \mathrm{~h}$ co-cultivation with A. tumefaciens. Methanolic extract of elicited $H$. perforatum cells showing higher antimicrobial activity than the equivalent extract of control $H$. perforatum cells, against $A$. tumefaciens colony formation. 
(Fig. 7). Thus, the antimicrobial potential of HP cells has been increased 10 times after elicitation, which can be attributed to the xanthones accumulation.

Since the methanolic extract of control cells also showed inhibition of A. tumefaciens at higher concentrations, it can be concluded that antimicrobial compounds are present in control cells too; but at relatively low concentrations, acting as phytoanticipins (Dixon, 2001). With biotic elicitation, the amount of total xanthones increased and new xanthones are produced, eventually to achieve a higher biological response, i.e. killing of bacterial cells.

2.3.2. De novo synthesized paxanthone display antimicrobial activity

From earlier studies, it is found that many xanthones possess antimicrobial activities against bacteria (Suksamrarn et al., 2003, 2006; Pinheiro et al., 2003; Laphookhieo et al., 2006; Xiao et al., 2008). Hence, we studied the antimicrobial activities of the four xanthones identified in the elicited HP cells (peaks 1-4 of Figs. $1 \mathrm{~b}$ and $\mathrm{c}$ ) by disc diffusion method. Of the four tested, only paxanthone (4) showed a clear inhibition zone against $A$. tumefaciens growth (Fig. 8a). So, not all of the xanthones produced by HP cells after elicitation have antimicrobial activity. The dose-dependent antimicrobial activity of paxanthone was studied by incorporating varying concentrations of paxanthone in A. tumefaciens suspension.

a
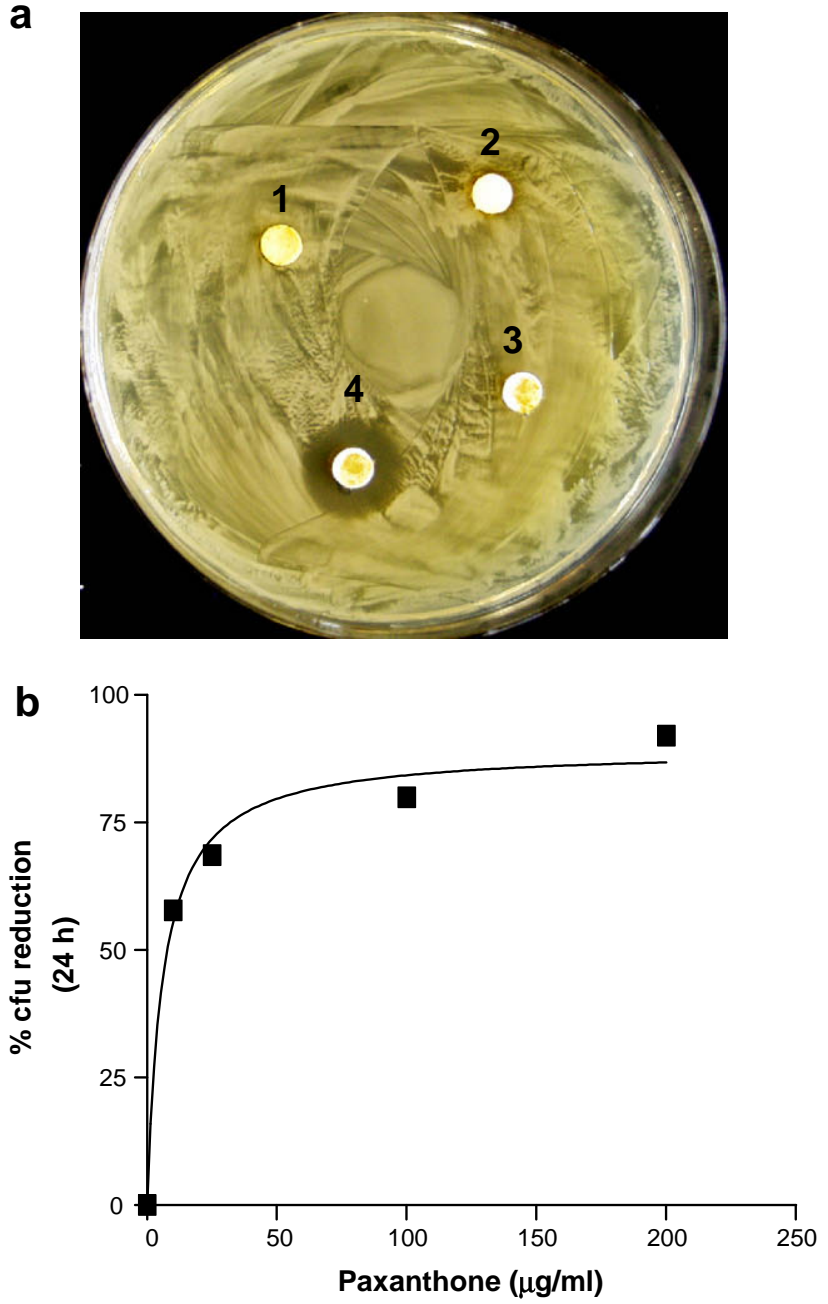

Fig. 8. Antimicrobial potential of de novo xanthones (1-4) isolated from elicited HP cells against $A$. tumefaciens. Among the four xanthones tested, only paxanthone (1) showed a clear zone of $A$. tumefaciens inhibition in disc diffusion method (a) and when incorporated into $A$. tumefaciens suspension, showed a concentrationdependent colony forming unit reduction (b).

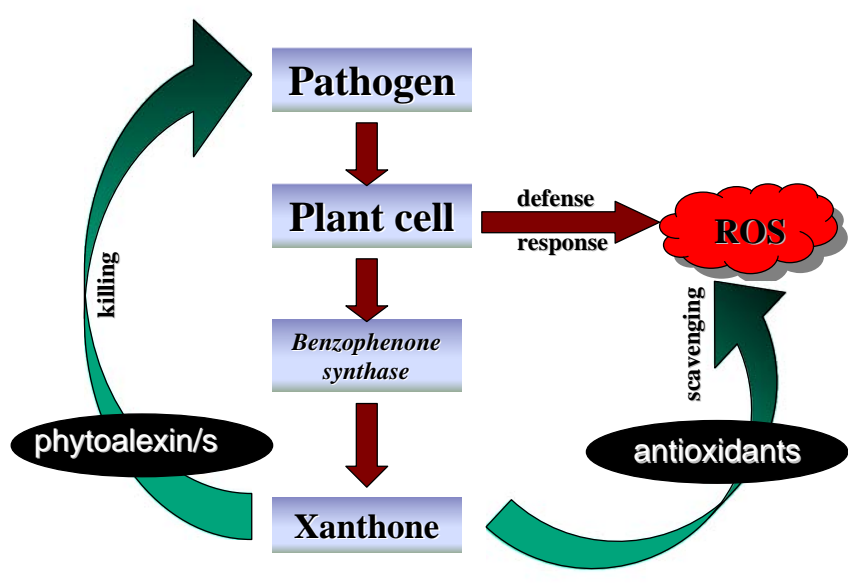

Fig. 9. Results of the present study explaining the significance of xanthones in this plant-pathogen interaction is summarized as a model.

As seen in Fig. 8b, with the maximum concentration of paxanthone tested $(200 \mu \mathrm{g} / \mathrm{ml})$, we did not observe $100 \%$ reduction of $A$. tumefeciens viability. In contrast, a concentration of methanolic extract that is equivalent to $20 \mathrm{mg}$ dry wt elicited cells/ml was sufficient to achieve $100 \%$ reduction in $A$. tumefaciens viability in $24 \mathrm{~h}$ (Fig. 7 ). Hence we believe antimicrobial compound(s) other than paxanthone or a synergism between this xanthone and other compounds of elicited cells might exist.

Pinheiro et al. (2003) had reported that assiguxanthone-B, a xanthone isolated from Kielmeyera variabilis showed only a moderate antibacterial activity (minimal inhibitory concentration $=25.0 \mu \mathrm{g} / \mathrm{ml}$ ) against Bacillus subtilis, in contrast to the methanolic extract of the plant (minimal inhibitory concentration $=1.95 \mu \mathrm{g} / \mathrm{ml}$ ). They found that the antimicrobial potential of assiguxanthone-B could be increased 4-fold, when combined with 1,3,5,6-tetrahydroxy-2-prenyl xanthone. Mixture of the two was able to inhibit B. subtilis at $6.25 \mu \mathrm{g} / \mathrm{ml}$ concentration. This observation demonstrates that the combination was active at much lower concentrations than each of the single compounds. Other evidences (Briskin, 2000) also indicate that many complex phytomedicines (plant extracts) exert biological or pharmaceutical effects through synergistic actions of several compounds.

\section{Conclusion}

In summary, we provide evidence for the activation of secondary metabolism in HP cells in general and xanthone biosynthesis in particular under elicitation by A. tumefaciens co-cultivation. We also present data that show the activation of xanthone biosynthesis having dual defense function in HP as described in the model (Fig. 9). On the one hand, xanthones constitute a powerful antioxidant system of protecting the host cells from self-generated ROS and subsequent oxidative damage. On the other hand, xanthones have also the potential to act as phytoalexin to help the host to impair and eventually kill the pathogen. In fact, both functions may help to prevent disease development by their concerted action.

\section{Experimental}

\subsection{Growth and elicitation of HP cells}

H. perforatum cell suspension culture was established from the variety 'Helos' (Richters seeds, Ontario, Canada) and maintained as per Dias et al. (2001). Five days after subculture, cells suspensions from several flasks were aseptically collected into a sterile beaker 
and the cell density was estimated in an improved Neubauer haemocytometer (Neubauer, Wertheim, Germany). After adjusting the cell concentration to about $5000 \mathrm{HP}$ cells/ml with sterile MS medium, $80 \mathrm{ml}$ aliquots were redistributed to each flask. A. tumefaciens stock was prepared as described before (Franklin et al., 2008). A set of 10 flasks, each containing $80 \mathrm{ml}$ of this HP cell suspension, were inoculated $A$. tumefaciens such that to reach $250 \times 10^{7}$ bacterial cells $/ \mathrm{ml}$. Another set of 10 flasks each containing $80 \mathrm{ml}$ of just HP cell suspension served as control. Treated and control cultures were incubated in growth chamber at $25^{\circ} \mathrm{C}$ under a photoperiod of $16 \mathrm{~h}$ light. After $24 \mathrm{~h}$ (or at the time indicated) cells were harvested by vacuum filtration and freeze-dried.

\subsection{Measurements of reactive oxygen species (ROS) and membrane lipid peroxidation}

\subsubsection{Detection of ROS in the intracellular space}

Intracellular ROS production in control and co-cultivated cells was measured using the fluorogenic dichlorodihydrofluorescein diacetate $\left(\mathrm{H}_{2} \mathrm{DCFDA}\right)$ probe (Invitrogen, Germany). In this method, the de-acetylation of $\mathrm{H}_{2}$ DCFDA by cellular esterases results in the production of an oxidant-sensitive compound dichlorodihydrofluorescein $\left(\mathrm{H}_{2} \mathrm{DCF}\right)$, which can be determined spectroflourimetrically.

To measure the intracellular ROS, $1.0 \mathrm{ml} \mathrm{HP}$ cell suspension culture from the treatment and control were transferred to Eppendorf tubes containing $10 \mu \mathrm{l}$ of $200 \mu \mathrm{M} \mathrm{H}_{2}$ DCFDA at different time intervals $(0,15,30,60,120,180$ and $240 \mathrm{~min})$ of $A$. tumefaciens inoculation. The mixture was vortexed $20 \mathrm{~s}$ and incubated in dark for $15 \mathrm{~min}$. Then, the cells were spun down in a table-top centrifuge at $6000 \mathrm{~g}$ for $30 \mathrm{~s}$ and $0.5 \mathrm{ml}$ supernatant was taken in a plastic cuvette containing $2.5 \mathrm{ml}$ sterile distilled $\mathrm{H}_{2} \mathrm{O}$. The fluorescence was read in a spectroflourimeter (Perkin Elmer LS50 Luminescence spectrometer, Buckinghamshire, UK) with $488 \mathrm{~nm}$ excitation and $525 \mathrm{~nm}$ emission for $1 \mathrm{~s}$.

\subsubsection{Detection of ROS in the extracellular space}

Hydrogen peroxide $\left(\mathrm{H}_{2} \mathrm{O}_{2}\right)$ concentration in the medium was measured by Ferric-xylenol orange (FOX1) method (Wolff, 1994). This method is based on the peroxide-mediated oxidation of $\mathrm{Fe}^{2+}$, followed by the reaction of $\mathrm{Fe}^{3+}$ with xylenol orange. This method is extremely sensitive and used to measure low levels of $\mathrm{H}_{2} \mathrm{O}$-soluble hydroperoxide present in the aqueous phase.

From the control and treated cultures, $1.0 \mathrm{ml}$ suspension was taken in an Eppendorf tube and centrifuged in order to pellet the cells down. Then, $500 \mu \mathrm{l}$ of the supernatant was transferred to Eppendorf tubes containing $500 \mu \mathrm{l}$ of xylanol orange reagent $\left(500 \mu \mathrm{M} \mathrm{NH} \mathrm{NeSO}_{4}, 50 \mathrm{mM} \mathrm{H}_{2} \mathrm{SO}_{4}, 200 \mu \mathrm{M}\right.$ xylenol orange, and $200 \mathrm{mM}$ sorbitol). The mixture was vortexed briefly and incubated in dark for $45 \mathrm{~min}$. Absorbance of the $\mathrm{Fe}^{3+}$-xylenol orange complex was measured in a spectrophotometer at $560 \mathrm{~nm}$ and the concentration of $\mathrm{H}_{2} \mathrm{O}_{2}$ in the medium was calculated by plotting those values on $\mathrm{H}_{2} \mathrm{O}_{2}$ standard graph.

\subsubsection{Detection of ROS-induced membrane lipid peroxidation in HP cells}

HP cells were harvested by vacuum filtration after 24, 48, 72 and $120 \mathrm{~h}$ of $A$. tumefaciens inoculation. Membrane lipid peroxidation was determined by measuring the amount of MDA as described by Unyayar et al. (2006). Briefly, $200 \mathrm{mg}$ fr. wt of cells were homogenized in $1 \mathrm{ml}$ of $5 \%$ trichloroacetic acid (TCA) solution. The homogenates were centrifuged at $12000 \mathrm{rpm}$ for $15 \mathrm{~min}$ at room temperature. A $0.5 \mathrm{ml}$ aliquot was mixed with $0.5 \mathrm{ml}$ freshly prepared TBA reagent $(0.5 \%$ thiobarbituric acid (TBA) in $20 \%$ TCA) in a screw cap tube and heated at $96^{\circ} \mathrm{C}$ in a boiling water bath. After $25 \mathrm{~min}$, the tubes were snap-cooled in ice to stop the reaction and centrifuged in a table-top centrifuge at $10000 \mathrm{rpm}$ for $5 \mathrm{~min}$. Absorbance of the supernatant was recorded at $532 \mathrm{~nm}$ and corrected for non-specific turbidity by subtracting the absorbance at $600 \mathrm{~nm}$. Reaction mixture containing $0.5 \mathrm{ml} \mathrm{5 \%}$ TCA and $0.5 \mathrm{ml}$ of TBA reagent served as blank. MDA content was determined using the absorption coefficient of $1.56 \times 10^{5}$ $\mathrm{cm}^{2} \mathrm{~mol}^{-1}$.

\subsection{Extraction and analysis of phenolics from HP cells}

Equal quantity of HP biomass of control and elicited cells were extracted under dark in $90 \% \mathrm{MeOH}$. Briefly, $4 \mathrm{~g}$ dry wt was taken in a Falcon tube that contained $40 \mathrm{ml} 90 \% \mathrm{MeOH}$ and sonicated $1 \mathrm{~h}$ and kept under dark for $24 \mathrm{~h}$ with frequent mixing. Cell debris was spun down by centrifugation at 3,000 $15 \mathrm{~min}$ in a table-top centrifuge. The supernatant was evaporated under vacuum, and dissolved in $2 \mathrm{ml}$ of DMSO to obtain $2 \mathrm{mg}$ dry wt/ $\mu \mathrm{l}$ final concentration. Phenolic compounds were analyzed by HPLC-DAD as described previously (Dias et al., 1999). Chromatographic separation was carried out on an RP C18 column (Merck, Germany), using $\mathrm{H}_{2} \mathrm{O} / \mathrm{HCO}_{2} \mathrm{H}(99: 1)$ and $\mathrm{MeOH}$ as the mobile phases and absorbance was recorded at 254, 350 and $590 \mathrm{~nm}$.

The quantification of the phenolic constituents was done by the external standard method, using a solution containing chlorogenic acid, $p$-coumaric acid, quercetin, quercetrin, hypericin and mangiferin as reference compounds in $\mathrm{MeOH}$. Flavonoids were quantified as quercetin equivalents at $350 \mathrm{~nm}$ and xanthones as mangiferin equivalents at $254 \mathrm{~nm}$.

\subsection{RNA isolation and blot hybridization}

About $500 \mathrm{mg}$ fr. wt HP cells were collected after 0, 4, 12 and $24 \mathrm{~h}$ A. tumefaciens addition to the cultures and frozen in liquid nitrogen. Total RNA was isolated according to Çakir et al. (2003), denatured, separated on agarose-formaldehyde gel and transferred to nylon membrane (Hybond- $\mathrm{N}^{\circledR}$, Amersham Biosciences, Buckingham, UK) by capillary transfer. DNA fragments specific to phenylalanine ammonia lyase (PAL), 4-coumarate:CoA ligase (4CL) and benzophenone synthase (BPS) cDNAs (from $H$. perforatum) were labeled with $\left[\alpha-{ }^{32} \mathrm{P}\right]$ dCTP (Amersham Biosciences) using Prime-aGene $^{\circledR}$ labeling kit (Promega, Madison, WI, USA) and used as hybridization probe in $2 \mathrm{X}$ SSC at $65^{\circ} \mathrm{C}$. Blots were washed twice with $2 \mathrm{X}$ SSC $+0.1 \%$ SDS each for $15 \mathrm{~min}$ followed by $0.1 \mathrm{X}$ SSC $+0.1 \%$ SDS for $5 \mathrm{~min}$ at $65^{\circ} \mathrm{C}$. The blots were exposed to the imaging screen for $12 \mathrm{~h}$ and scanned in a Personal Molecular Ima$\operatorname{ger}^{\circledR}$ (Bio-Rad, Hercules, CA, USA).

\subsection{Free radical-scavenger activity (DPPH assay)}

The antiradical activity of methanolic extracts from HP cells and isolated xanthones (1,3,6,7-tetrahydroxy-8-prenyl xanthone, 1,3,6,7-tetrahydroxy-2-prenyl xanthone, 1,3,7-trihydroxy-6-methoxy-8-prenyl xanthone and paxanthone) were determined by the 1,1-diphenyl-2-picrylhydrazyl (DPPH) assay, as described previously (Silva et al., 2005). The antiradical activity of each sample was evaluated using a series of dilutions, in order to obtain a large spectrum of sample concentrations. The reaction solution consisted of $0.1 \mathrm{ml}$ diluted sample and $1.4 \mathrm{ml}$ of $80 \mu \mathrm{M}$ DPPH (dissolved in $100 \%$ EtOH). The absorbance was monitored continuously at $515 \mathrm{~nm}$ with a Perkin-Elmer UV/VIS Spectrometer Lambda2, assuring that the reaction was complete (plateau state). The percentage of reduced DPPH at steady state (DPPH-R) was calculated and these values were plotted against the concentrations methanolic extracts or of pure compounds. A decrease by $50 \%$ of the initial DPPH concentration was defined as the half maximal effective concentration $\left(\mathrm{EC}_{50}\right)$. 


\subsection{Inhibition of synaptosomal lipid peroxidation (TBARS assay)}

Synaptosomal fraction of male Wistar rat brains was isolated and thiobarbituric acid reactive substance (TBARS) assay was performed as described previously (Silva et al., 2005). Briefly, lipid peroxidation was induced in synaptosomes using an oxidant pair $(800 \mu \mathrm{M}$ ascorbic acid and $2.5 \mu \mathrm{M} \mathrm{FeSO} 4)$ in Krebs buffer (132 mM NaCl, $4 \mathrm{mM} \mathrm{KCl}, 1.4 \mathrm{mM} \mathrm{MgCl}, 1 \mathrm{mM} \mathrm{CaCl}_{2}, 6 \mathrm{mM}$ glucose, $10 \mathrm{mM}$ Hepes-Na, pH 7.4) at $37^{\circ} \mathrm{C}$ for $15 \mathrm{~min}$. Synaptosomes, without the oxidant pair served as negative control to calculate the basal lipid peroxidation level. The effect of methanolic extracts and isolated xanthones (1,3,6,7-tetrahydroxy-8-prenyl xanthone, 1,3,6,7-tetrahydroxy-2-prenyl xanthone, 1,3,7-trihydroxy-6-methoxy-8-prenyl xanthone and paxanthone) on lipid peroxidation was recorded by adding them to the reaction mixture at different concentration. The malondialdehyde (MDA)-thiobarbituric acid (TBA) complex was recorded at $530 \mathrm{~nm}$, after reaction of samples with trichloroacetic acid $(40 \%, \mathrm{w} / \mathrm{v})$ and $\mathrm{TBA}(0.67 \%, \mathrm{w} / \mathrm{v})\left(96^{\circ} \mathrm{C}\right.$, $10 \mathrm{~min}$ ) and centrifugation $(3000 \mathrm{~g}, 10 \mathrm{~min})$. The amount of MDA formed was calculated using the absorption coefficient of $1.56 \times 10^{5} \mathrm{~cm}^{2} \mathrm{~mol}^{-1}$. Values were corrected for the levels of basal peroxidation, obtained during the assay. A decrease by $50 \%$ of the value of lipid peroxidation, induced by ascorbate- $\mathrm{Fe}^{2+}$, was defined as the $\mathrm{EC}_{50}$.

\subsection{Determination of antibacterial activity (colony forming units and disc diffusion)}

The stock $A$. tumefaciens suspension obtained as described before (Franklin et al., 2008) was diluted in MS medium to approximately $250 \times 10^{8} \mathrm{CFU} / \mathrm{ml}$. Aliquots $(100 \mu \mathrm{l})$ from this bacterial suspension were then added to $900 \mu \mathrm{l}$ of sterile MS medium containing methanolic extracts of control and elicited HP cells, to achieve a range of final concentrations $(0,5,10,25,50$ and $100 \mu \mathrm{l} / \mathrm{ml})$. Similarly, paxanthone $(5 \mathrm{mg} / \mathrm{ml}$ dissolved in DMSO) was incorporated into bacterial suspension at different concentrations $(0,10,25,100$ and $200 \mu \mathrm{g} / \mathrm{ml})$. Bacterial suspensions that received the corresponding concentration of DMSO $(0,2,5,20$ and $40 \mu \mathrm{l} / \mathrm{ml}$ ) served as control for paxanthone treatment. All the samples were maintained on a shaker at $200 \mathrm{rpm}$ at $28{ }^{\circ} \mathrm{C}$ for $24 \mathrm{~h}$. Subsequently, $100 \mu \mathrm{l}$ aliquot from each sample was serially diluted to $10^{-6}$ and spread on Petri dishes containing $20 \mathrm{ml}$ Luria-Bertani (LB) medium augmented with $25 \mathrm{mg} / \mathrm{l}$ rifampicin and $50 \mathrm{mg} / \mathrm{l}$ kanamycin. The colony forming units on each plate were counted after incubation for 2 days at $28{ }^{\circ} \mathrm{C}$ and the percentage of viability was calculated.

Qualitative antimicrobial activity of isolated xanthones was determined by a classical disc diffusion assay. All the isolated xanthones (1,3,6,7-tetrahydroxy-8-prenyl xanthone, 1,3,6,7-tetrahydroxy-2-prenyl xanthone, 1,3,7-trihydroxy-6-methoxy-8-prenyl xanthone and paxanthone) were dissolved separately in DMSO to obtain $5 \mathrm{mg} / \mathrm{ml}$ stock concentration. Sterile paper discs loaded with $10 \mu \mathrm{l}$ were dried at RT and placed onto LB medium spread with $100 \mu \mathrm{l} \mathrm{A}$. tumefaciens suspension $\left(250 \times 10^{7} / \mathrm{ml}\right)$ and incubated for 2 days at $28^{\circ} \mathrm{C}$.

\subsection{Statistical analyses}

For all the treatments, at least three independent experiments each with three replica were done. Flavonoids and xanthone content of control and elicited HP cells were compared statistically by two way ANOVA followed by Bonferroni post-hoc test. In the same manner, the levels of membrane lipid peroxidation in HP cells after different time periods of $A$. tumefaciens inoculation were compared. Statistical analyses were performed using GraphPad
Prism Software, version 5.00 for Windows (GraphPad Software, San Diego, CA, USA).

\section{Acknowledgements}

This work was supported by Fundação para a Ciência e Tecnologia (POCTI/AGR/40283/2001). Postdoctoral fellowship (SFRH/BPD/ 17102/2004) awarded to G. Franklin by Fundação para a Ciência e Tecnologia is gratefully acknowledged. L. Conceição is supported by Fundação para a Ciência e Tecnologia PhD fellowship (SFRH/BD/ 13318/2003).

\section{References}

Abd El-Mawla, A.M.A., Beerhues, L., 2002. Benzoic acid biosynthesis in cell cultures of Hypericum androsaemum. Planta 214, 727-733.

Abd El-Mawla, A.M.A., Schmidt, W., Beerhues, L., 2001. Cinnamic acid is a precursor of benzoic acids in cell cultures of Hypericum androsaemum L. but not in cell cultures of Centaurium erythraea RAFN. Planta 212, 288-293.

Arias, M.C., Luna, C., Rodríguez, M., Lenardon, S., Taleisnik, E., 2005. Sunflower chlorotic mottle virus in compatible interactions with sunflower: ROS generation and antioxidant response. Eur. J. Plant Pathol. 113, 223-232.

Banerjee, S., Sur, T.K., Mandal, S., Das, P.C., Sikdar, S., 2000. Assessment of the antiinflammatory effects of Swertia chirata in acute and chronic experimental models in male albino rats. Ind. J. Pharmacol. 32, 21-24.

Beerhues, L., 1996. Benzophenone synthase from cultured cells of Centaurium erythraea. FEBS Lett. 383, 264-266.

Beerhues, L., Berger, U., 1995. Differential accumulation of xanthones in methyljasmonate- and yeast-extract-treated cell cultures of Centaurium erythraea and Centaurium littorale. Planta 197, 608-612.

Boonsri, S., Karalai, C., Ponglimanont, C., Kanjana-opas, A., Chantrapromma, K., 2006 Antibacterial and cytotoxic xanthones from the roots of Cratoxylum formosum. Phytochemistry 67, 723-727.

Briskin, D.P., 2000. Medicinal plants and phytomedicines. Linking plant biochemistry and physiology to human health. Plant Physiol. 124, 507-554.

Cakir, B., Agasse, A., Gaillard, C., Saumonneau, A., Delrot, S., Atanassova, R., 2003. A grape ASR protein involved in sugar and abscisic acid signaling. Plant Cell 15, 2165-2180.

Chen, Z., Silva, H., Klessig, D.F., 1993. Active oxygen species in the induction of plant systemic acquired resistance by salicylic acid. Science 262, 1883-1886.

Conceição, L.F.R., Ferreres, F., Tavares, R.M., Dias, A.C.P., 2006. Induction of phenolic compounds in Hypericum perforatum L. cells by Colletotrichum gloeosporioides elicitation.. Phytochemistry 67, 149-155.

Dias, A.C.P., 2003. The potential of in vitro cultures of Hypericum perforatum and Hypericum androsaemum to produce interesting pharmaceutical compounds. In: Ernest, E. (Ed.), Hypericum. Taylor and Francis, London, New York, pp. 137-154

Dias, A.C.P., Seabra, R.M., Andrade, B., Ferreira, M.F., 1999. The development and evaluation of a HPLC-DAD method for the analysis of the phenolic fractions from in vivo and in vitro biomass of Hypericum species. J. Liq. Chromatogr. 22 215-227.

Dias, A.C.P., Seabra, R.M., Andrade, B., Ferreres, F., Ferreira, M.F., 2000. Xanthone biosynthesis and accumulation in calli and suspended cells of Hypericum androsaemum. Plant Sci. 150, 93-101.

Dias, A.C.P., Seabra, R.M., Andrade, B., Ferreres, F., Ferreira, M.F., 2001. Xanthone production in calli and suspended cells of Hypericum perforatum. J. Plant Physiol. 158, 821-827.

Dixon, R.A., 2001. Natural products and plant disease resistance. Nature 411, 843 847.

Dixon, R.A., Paiva, N.L., 1995. Stress-induced phenylpropanoid metabolism. Plant Cell 7, 1085-1097.

Ehlting, J., Büttner, D., Wang, Q., Douglas, C.J., Somssich, I.E., Kombrink, E., 1999 Three 4-coumarate:coenzyme A ligases in Arabidopsis thaliana represent two evolutionarily divergent classes in angiosperms. Plant J. 19, 9-20.

Ferrari, F., Pasqua, G., Monacelli, B., Cimino, P., Botta, B., 2005. Xanthones from calli of Hypericum perforatum subsp. perforatum. Nat. Prod. Res. 19, 171-176.

Foti, M.C., Sharma, S.K., Shakya, G., Prasad, A.K., Nicolosi, G., Paolo, B., Ghosh, B., Raj, H.G., Rastogi, R.C., Parmar, V.S., 2005. Biopolyphenolics as antioxidants: Studies under an Indo-Italian CSIR-CNR project. Pure Appl. Chem. 77, 91-101.

Foyer, C.H., Noctor, G., 2005. Oxidant and antioxidant signalling in plants: a reevaluation of the concept of oxidative stress in a physiological context. Plant Cell and Environ. 28, 1056-1071.

Franklin, G., Oliveira, M., Dias, A.C.P., 2007. Production of transgenic Hypericum perforatum plants via particle bombardment-mediated transformation of novel organogenic cell suspension cultures. Plant Sci. 172, 1193-1203.

Franklin, G., Conceiçao, L.F.R., Kombrink, E., Dias, A.C.P., 2008. Hypericum perforatum plant cells reduce Agrobacterium viability during co-cultivation. Planta 227 1401-1408.

Iinuma, M., Tosa, H., Tanaka, T., Asai, F.F., Kobayashi, Y., Shimano, R., Miyauchi, K. 1996. Antibacterial activity of xanthones from Guttiferaceous plants against methicillin-resistant Staphylococcus aureus. J. Pharm. Pharmacol. 48, 861-865. 
Ishiguro, K., Nagata, S., Oku, H., Yamaki, M., 2002. Bisxanthones from Hypericum japonicum: Inhibitors of PAF-induced hypotension. Planta Med. 68, 258-261.

Ito, C., Itoigawa, M., Takakura, T., Ruangrungsi, N., Enjo, F., Tokuda, H., Nishino, H., Furukawa, H., 2003. Chemical constituents of Garcinia fusca: structure elucidation of eight new xanthone and their cancer chemopreventive activity. J. Nat. Prod. 66, 200-205.

Jiang, D.-J., Dai, Z., Li, Y.-J., 2004. Pharmacological effects of xanthones as cardiovascular protective agents. Cardiovasc. Drug Rev. 22, 91-102.

Laphookhieo, S., Syers, J.K., Kiattansakul, R., Chantrapromma, K., 2006. Cytotoxic and antimalarial prenylated xanthones from Cratoxylum cochinchinense. Chem. Pharm. Bull. 54, 745-747.

Oku, H., Ueda, Y., Iinuma, M., Ishiguro, K., 2005. Inhibitory effects of xanthones from Guttiferae plants on PAF-induced hypotension in mice. Planta Med. 71, 90-92.

Peters, S., Schmidt, W., Beerhues, L., 1998. Regioselective oxidative phenol couplings of 2, 3'4, 6-tetrahydroxybenzophenone in cell cultures of Centaurium erythraed. Planta 204, 64-69.

Pinheiro, L., Nakamura, C.V., Filho, B.P.D., Ferreira, A.G., Young, M.C.M., Cortez D.A.G., 2003. Antibacterial xanthones from Kielmeyera variabilis Mart. (Clusiaceae). Mem. Inst. Oswaldo Cruz Rio de Janeiro 98, 549-552.

Pinto, M.M.M., Sousa, M.E., Nascimento, M.S.J., 2005. Xanthone derivatives: new insights in biological activities. Curr. Med. Chem. 12, 2517-2538.

Rukachaisirikul, V., Kamkaew, M., Sukavisit, D., Phongpaichit, S., Sawangchote, P., Taylor, W., 2003. Antibacterial xanthones from the leaves of Garcinia nigrolineata. J. Nat. Prod. 66, 1531-1535.

Rukachaisirikul, V., Tadpetch, K., Watthanaphanit, A., Saengsanae, N., Phongpaichit, S., 2005. Benzopyran, biphenyl, and tetraoxygenated xanthone derivatives from the twigs of Garcinia nigrolineata. J. Nat. Prod. 68, 1218-1221.

Sakagami, Y., Iinuma, M., Piyasena, K.G.N.P., Dharmaratne, H.R.W., 2005 Antibacterial activity of a-mangostin against vancomycin resistant Enterococc (VRE) and synergism with antibiotics. Phytomedicine 12, 203-208.

Scandalios, J.G., 1993. Oxygen stress and superoxide dismutases. Plant Physiol. 101, 7-12.

Schmidt, W., Beerhues, L., 1997. Alternative pathways of xanthone biosynthesis in cell cultures of Hypericum androsaemum L. FEBS Lett. 420, 143-146.

Shao, H.B., Chu, L.Y., Lu, Z.H., Kang, C.M., 2008. Primary antioxidant free radical scavenging and redox signaling pathways in higher plant cells. Int. J. Biol. Sci. 4, 8-14.

Sharan, M., Taguchi, G., Gonda, K., Jouke, T., Shimosaka, M., Hayashida, N., Okazaki, M., 1998. Effects of methyl jasmonate and elicitor on the activation of phenylalanine ammonia-lyase and the accumulation of scopoletin and scopolin in tobacco cell cultures. Plant Sci. 132, 13-19.

Silva, B.A., Ferreres, F., Malva, J.O., Dias, AC.P., 2005. Phytochemical and antioxidant characterization of Hypericum perforatum alcoholic extracts. Food Chem. 90, 157-167.

Sukpondma, Y., Rukachaisirikul, V., Phongpaichit, S., 2005. Xanthone and sesquiterpene derivatives from the fruits of Garcinia scortechinii. J. Nat. Prod. 68, 1010-1017.

Suksamrarn, S., Suwannapoch, N., Phakhodee, W., Thanuhiranlert, J., Ratananukul, P., Chimnoi, N., Suksamrarn, A., 2003. Antimycobacterial activity of prenylated xanthones from the fruits of Garcinia mangostana. Chem. Pharm. Bull. 51, 857859.

Suksamrarn, S., Komutiban, O., Ratananukul, P., Chimnoi, N., Lartpornmatulee, N., Suksamrarn, A., 2006. Cytotoxic prenylated xanthones from the young fruit of Garcinia mangostana. Chem. Pharm. Bull. 54, 301-305.

Tanaka, N., Takaishi, Y., 2006. Xanthones from Hypericum chinense. Phytochemistry 67, 2146-2151.

Tian, Y.H., Kim, H.C., Cui, J.M., Kim, Y.C., 2005. Hepatoprotective constituents of Cudrania tricuspidata. Arch. Pharm. Res. 28, 44-48.

Unyayar, S., Celik, A., Cekic, F.O., Gozel, A., 2006. Cadmium-induced genotoxicity, cytotoxicity and lipid peroxidation in Allium sativum and Vicia faba. Mutagenesis 21, 77-81.

Vanderauwera, S., Zimmermann, P., Rombauts, S., Vandenabeele, S., Langebartels, C., Gruissem, W., Inzé, Breusegem F.V., 2005. Genome-wide analysis of hydrogen peroxide-regulated gene expression in Arabidopsis reveals a high light-induced transcriptional cluster involved in anthocyanin biosynthesis. Plant Physiol. 139, 806-821.

Wolff, S.P., 1994. Ferrous ion oxidation in presence of ferric ion indicator xylenol orange for measurement of hydroperoxides. Methods Enzymol. 233, 182-189.

Xiao, Z.Y., Shiu, W.K.P., Zeng, Y.H., Mu, Q., Gibbons, S., 2008. A naturally occurring inhibitory agent from Hypericum sampsonii with activity against MultidrugResistant Staphylococcus aureus. Pharmaceut. Biol. 46, 250-253.

Yimdjo, M.C., Azebaze, A.G., Nkengfack, A.E., Meyer, A.M., Bodo, B., Fomum, Z.T., 2004. Antimicrobial and cytotoxic agents from Calophyllum inophyllum. Phytochemistry 65, 2789-2795.

Zou, J., Jin, D., Chen, W., Wang, J., Liu, Q., Zhu, X., Zhao, W., 2005. Selective cyclooxygenase-2 inhibitors from Calophyllum membranaceum. J. Nat. Prod. 68, 1514-1518. 